ISSN: 2224-0616

Int. J . Agril. Res. Innov. \& Tech. 6 (2): 24-30, December, 2016 Available online at http://www.ijarit.webs.com

\title{
SYMPTOMATOLOGY OF FUNGAL COMPETITORS ON OYSTER MUSHROOM'S SPAWN PACKETS AND IN VITRO EVALUATION USING PHYTOEXTRACTS AND A FUNGICIDE
}

\author{
F.A. Shamoli1, A. Khair', M. Bhadra'1,3, M.A. Hossain'2and M.M. Sikder ${ }^{*}$
}

Received 28 August 2016, Revised 4 December 2016, Accepted 27 December 2016, Published online 31 December 2016

\begin{abstract}
An experiment was conducted to find out the fungal competitors and symptom studies in damaged Oyster Mushroom spawn packets at National Mushroom Development and Extension Center, Savar, Dhaka, Bangladesh. A total of nine fungal competitors of oyster mushroom were isolated and identified namely- Trichoderma harzianum Rifai, T. viride Pers. (Green strain), T. viride Pers. (Yellow strain), T. koningii Oudem, Mucor hiemalis Wehmer, Papulaspora byssina Hotson, Neurospora sp. Shear and B.O. Dodge., Aspergillus flavus Link., and Botryodiplodia theobromae Pat. on the basis of microscopic, morphological and cultural characteristics. To produce oyster mushroom in an eco-friendly manner and to find out their antifungal potency, 23 plant species belonging to 19 families were screened out against isolated nine fungal competitors of oyster mushroom. Among 23 extracts, the maximum (44\%) mycelial inhibition of T. harzianum was found due to Aegle marmelos whereas Eclipta alba showed the highest mycelial inhibition (62\%) of T. viride (Green strain); in case of T. viride (Yellow strain), Cassia tora exhibited the highest mycelial inhibition (39\%); Diospyros cordifolia showed the maximum mycelial inhibition (48\%) of T. koningii; Curcuma longa (rhizome) gave the maximum mycelial inhibition (90\%) of Neurospora sp. There were no significant effects found to control of P. byssina, B. theobromae, M. hiemalis and A. flavus due to 23 different types of botanicals tested. Trichoderma harzianum, T. viride (Green strain), T. viride (Yellow strain), T. koningii, A. flavus, Neurospora sp. and P. byssina was successfully inhibited by 30, 50 and $70 \mathrm{ppm}$ of fungicide-Bavistin 50 WP but B. theobromae and M. hiemalis were not affected by Bavistin at mentioned concentration.
\end{abstract}

Keywords: Oyster Mushroom, Fungal Competitors, Plant Extracts.

${ }^{1}$ Department of Botany, Jahangirnagar University, Savar, Dhaka-1342, Bangladesh

${ }^{2}$ National Mushroom Development and Extension Center, Savar, Dhaka, Bangladesh

${ }^{3}$ Department of Biology, Graduate School of Science, Kobe University, Japan

*Corresponding author's email: mmsbot@juniv.edu (M.M. Sikder)

\section{Introduction}

Oyster mushroom [Pleurotus ostreatus (Jacq.) P. Kumm.] is one of the popular and widely cultivated mushroom varieties in Bangladesh and cheaply available named as PO-2 at National Mushroom Development and Extension Centre (NAMDEC) and cultivated all the year round. A number of competitor moulds have been reported to occur in the substratum, which used for oyster mushroom production. Variations in the types of moulds are mainly due to the use of a diversity of substrates, different methods of substrate preparation and the conditions and containers used for cultivation. Different saprophytic and plant pathogenic fungi occurring in the substrate and competing with mushroom mycelium for space and nutrition are Aspergillus niger, A. flavus, Alternaria alternata, Drechslera bicolor, Fusarium moniliforme, Mucor sp., Penicillium sp., Rhizopus spp., Rhizpus stolonifer, Sclerotium rolfsii,, Trichoderma viride (Sharma et al., 2007; Sharma and Kumar, 2011). There might be an interaction between Trichoderma sp. and the mushroom due to the enzymatic action on substrate by mushroom that favors green mold fungal growth (Colavolpe et al., 2015). Antifungal activity of different plant extracts have been reported earlier by several investigators against a number of plant pathogens (Ashrafuzzaman et al., 1990). Present study was undertaken with the aim to investigate the symptoms produced due to fungal competitors of mushroom during mushroom production; isolation, identification of competitor fungi of Oyster mushrooms, to evaluate in vitro antifungal potency of several phytoextracts and fungicide against the fungal competitors. 


\section{Materials and Methods}

Symptomatological study of damaged
spawn packets, isolation and
identification of fungal competitors

On the basis of visual observation range of different symptoms were noticed in spawn packets where the mycelium of mushroom were damaged or dominated by the competitors. The symptoms and signs were closely and carefully observed. A total of ten infected spawn packets were taken randomly to isolate the mushroom competitors responsible for damaging as methods given by Dhingra and Sinclair (1985). Individual isolates were identified following Commonwealth Mycological Institute description as described by Barnett (1960) for imperfect fungi, Alexopolus et al. (1996) for perfect fungi.

\section{In vitro evalulation of phytoextracts and} fungicide-Bavistin $50 \mathrm{WP}$

A total of twenty three plant species belonging to 19 families were collected from different locations of Jahangirnagar University campus namelyAegle marmelos (L.) Correa., Axonopus compressus (Sw) P. Beauv., Blumea lacera (Burm. f) DC., Bougainvillea glabra Choisy, Calamus viminalis Willd., Cassia tora L., Catharanthus roseus L., Curcuma longa (leaf) L., Curcuma longa (rhizome) L., Diospyros cordifolia Roxb., Eclipta alba L., Hemidesmus indicus Br., Hollarhena antidysenterica (Linn) Wall., Ixora coccinea L., Lantana camara L., Melastoma malabathicum L., Mesua nagesarium Kost., Mucuna pruriens L., Pimenta acris Wt., Pteris sp. L., Rungia pectinata (L.) Nees, Catunaregam spinosa (Thunb) Tirveng., Zingiber offinale Rosc. Ethanol was used to extract the active constituent of plant materials. Filtration of extract through Membrane filters was carried out as described by Cappuccino and Sherman (1998). The extracts were tested by introducing $0.5 \mathrm{ml}$ of filtrate spreaded onto $20 \mathrm{ml}$ PDA media containing Petri plate and incubated at $30^{\circ} \mathrm{C}$ for five days. In a sterile Petri plate, $20 \mathrm{ml}$ of PDA was poured and 2 wells of $5 \mathrm{~mm}$ were dug at two sides. $100 \mathrm{\mu l}$ of each botanical were poured into these wells using sterile micropipette. Fungal discs $(5 \mathrm{~mm}$ ) were punched from 5 days old cultures of the test fungus and placed at the centre of the Petri plates to evaluate the efficacy of the extracts. Petri dish containing PDA medium with each fungal inoculums alone served as control. The plates were incubated at room temperature $\left(28 \pm 2^{\circ} \mathrm{C}\right)$ for 7 days. The mean radial growth of the fungal colony was recorded after 7 days. The efficacy of extract was determined by comparing the radial growth in treatment ( $\mathrm{T}$ ) with the control (C). The inhibition percentage (I) was calculated using the formula given by Vincent (1947):

Mycelial inhibition $(\%)=\frac{\mathrm{C}-\mathrm{T}}{\mathrm{C}} \times 100$

Three different concentrations (30, 50, $70 \mathrm{ppm})$ of a recommended fungicide-Bavistin $50 \mathrm{WP}$ (Carbendazim) were used in the experiment. PDA medium served with requisite amount of distilled water and poured in sterile petri plate and inoculated with test fungus served as control. Each treatment was replicated thrice and kept at room temperature $\left(28 \pm 2^{\circ} \mathrm{C}\right)$ for 7 days. The inhibition percentages (I) of fungicides were calculated using the formula given by Vincent (1947). The data obtained from different treatments related to phytoextracts and fungicide were analyzed statistically to find out the variation resulting from experimental treatments using SPSS-18 programme.

\section{Results and Discussion}

\section{Symptomatological of fungal competitor in oy ster spawn packets}

The symptoms appeared in the spawn packets and observed damaging mushroom mycelium were distinctly different from each other depending on different causal competitors. The different symptoms appeared have been described in Table 1. A total of nine fungal competitors were identified in oyster spawn packets namely Trichoderma viride (green strain), Trichoderma viride (yellow strain), T. harzianum, T. koningii, Papulaspora byssina, Mucor hiemalis, Botrydiplodia theobromae, Aspergillus flavus, Neurospora sp.

Table 1. Different symptoms appeared in Oyster spawn packets due to different competitors.

\begin{tabular}{|c|c|}
\hline Causal organisms & Symptoms \\
\hline Trichoderma harzianum & $\begin{array}{l}\text { Appeared white in color and compete mushroom mycelium, distinctly showed } \\
\text { the green sporulation and ceased the growth of mushroom. }\end{array}$ \\
\hline $\begin{array}{l}\text { Trichoderma viride } \\
\text { (Green strain) }\end{array}$ & $\begin{array}{l}\text { Deep green and compact sporulation found growing over the mushroom } \\
\text { mycelium and covered the whole packet. }\end{array}$ \\
\hline $\begin{array}{l}\text { Trichoderma viride } \\
\text { (Yellow strain) }\end{array}$ & $\begin{array}{l}\text { Creamy white or yellowish, light green sporulation appeared over the spawn } \\
\text { packet. }\end{array}$ \\
\hline Trichoderma koningii & Green sporulation found spreaded over spawn packet. \\
\hline Mucor hiemalis & $\begin{array}{l}\text { Pinheaded mold became mature vigorously and run over mushroom for space } \\
\text { and nutrition. }\end{array}$ \\
\hline Botrydiplodia theobromae & Destroyed the spawn packet substrate and black acervuli appeared. \\
\hline Aspergillus flavus & Olive green powdery sporulation observed. \\
\hline Neurospora sp. & Pink colored vigorously growing mycelium observed covered mushroom. \\
\hline Papulaspora byssina & $\begin{array}{l}\text { Brown powdery substance recorded which completely covered the spawn } \\
\text { packet space. }\end{array}$ \\
\hline
\end{tabular}


The symptoms appeared and time of expression varied with the different species. Trichoderma spp. initially found to produce the denser compact mycelia compared to Pleurotus, which gradually turned green in color due to heavy sporulation, within two to three days, a characteristic symptom of green mold disease (Table 1). Trichoderma spp. having a green, green-yellow, or white color on the mushroom compost, compete with other mushrooms for nutrients, cause parasitic damage and no fruit bodies observed in infected spawn packets. The occurrence of different species of Trichoderma on Pleurotus spawn packets, the incidence of $T$. harzianum was the highest at low temperature. The incidence of $\mathrm{T}$. harzianum became lower while temperature raised but incidence of other Trichoderma spp. increased. The findings of the present study are in agreement with those described by Choi et al. (2003). Mushrooms infected with $\mathrm{T}$. harzianum developed larger, light brown spots (Dano, 2000); T. koningii developed reddish spots (Fletcher et al., 1989), T. viride developed dark brown spots (Rinker and Wuest, 1994), which are not similar to present findings. During present study, it was observed that T. harzianum and T. viride (green) caused maximum damage in mushroom production. Dano (2000) also reported the similar findings and cited that $\mathrm{T}$. harzianum and $\mathrm{T}$. viride are more severe than $\mathrm{T}$. koningii. The present findings are in agreement with the results of Sharma and Kumar (2011) who found the severe incidence of Green moulds (Trichoderma viride, T. harzianum, T. hamatum, T. koningii, Aspergillus spp., Penicillium cyclopium) and P. byssina in mushroom cultivation. Different nutrient sources like carbon and nitrogen, percent of high relative humidity (RH), hot temperatures, a fluctuation of mentioned factors, and the absence of light during spawn run are considered as an ideal environmental conditions for the growth of moulds which can easily lead to a contamination (Chen and Moy, 2004). Sharma et al. (2007) reported a number of fungi (namelyAspergillus spp., Penicillium spp., Trichoderma spp., Mucor spp., Rhizopus spp., Fusarium spp., and Papulospora spp.) in compost and casing soil during the cultivation of white button mushroom. Our results are also supported by Chinara and Mohopatra (2014) who observed a number of fungal competitors' namely-Aspergillus flavus, A. niger, Mucor sp., Penicillium sp., Sclerotium rolfsii and Trichoderma sp.

\section{In vitro evaluation of botanicals against mushroom competitors}

The present investigation revealed the antifungal activity of some botanicals against the isolated fungal competitors of oyster mushroom. Among 23 botanical extracts, Aegle marmelos showed the highest mycelia growth inhibition (44\%) of T. harzianum, followed by Zingiber offinale (12\%) while rest of 21 botanical extract did not show any inhibitory effect on green mould- T. harzianum (Table 2). In our study, Eclipta albashowed the highest inhibition (62\%) of T. viride (green strain), which was followed by Pteris sp. (44\%), Curcuma longa (44\%), Diospyros cordifolia (44\%). The other 6 phytoextracts of Aegle marmelos, Lantana camara, Cassia tora, Rungia pectinata, Pimenta acris, showed statistically similar inhibitory effects on $\mathrm{T}$. viride (green strain) (Table 3) while the rest of the 11 phytoextracts had no significant effects on T. viride. On the other hand, Cassia tora showed the highest mycelia inhibition (39\%) against T. viride (yellow strain) which was followed by Rungia pectinata, Aegle marmelos, Lantana camara and Pimenta acris (Table 4). The maximum inhibition (48\%) of T. koningiiwas found due to phytoextracts of Diospyros cordifolia, followed by Cassia tora (41.4\%), Blumea lacera (40\%) and Mucuna pruriens (37\%) (Table 5); other botanical extract of Rungia pectinata, Pimenta acris, Aegle marmelos and Curcuma longa showed similar significant inhibition effect on T. koningii while the rest of the 15 botanicals extract did not show any inhibitory effect on $\mathrm{T}$. koningii. There was a number of reports on green mould management by onion, garlic, neem, Juglans regia whereas in our study, Aegle marmelos, Eclipta alba, Pteris sp., Cassia tora, Diospyros cordifolia gave substantial mycelial inhibition of the green mould ( $\mathrm{T}$. harzianum, T. koningii, T. viride) associated with oyster mushroom substrate. Siddique et al. (2004) found the maximum inhibition due to the extract of onion (Allium cepa), followed by the extracts of Aegle marmelos and Wedelia chinensis. Shah et al. (2011) recorded the maximum mycelial inhibition (51.9\%) of Trichoderma due to Juglans regia, followed by Azadiracta indica (34.1\%), Allium sativum (28.4\%). Mishra (2009) found the effective control of Trichoderma viride by the use of Neem leaf extract, Neem cake solution and Neem saw dust. Narzari et al. (2007) reported that complete mycelial inhibition of T. harzianum was found by $0.4 \%$ concentration of Allium sativum (garlic) extract. Inam-ul-Haq et al. (2010) found that Azadirachta indica, and Citrus lemon was capable of controls pathogenic microbes ( $T$. harzianum) in oyster mushroom cultivation and increasing mushroom yield. Parvez et al. (2012) recorded the maximum mycelial inhibition (51.25\%) of green mould (T. harzianum) of mushroom substrate due to extract of Lantana camara, followed by Azadirachta indica (47.75\%), Allium cepa (34.85\% and A. sativum $(28.95 \%)$ 
Table 2. Effect of selected plant extracts on vegetative growth of T. harzianum.

\begin{tabular}{llc}
\hline Sl. No. & Plant name & Mycelial inhibition (\%) \\
\hline 1. & Aeglemarmelos (L.) Correa & $44 \pm 0.58 \mathrm{a}$ \\
2 & Zingiber offinale Rosc & $12 \pm 0.28 \mathrm{~b}$ \\
$3-23$. & Others 21 botanical extracts & Nil \\
\hline
\end{tabular}

Data recorded at 7 days of incubation, Data represents mean \pm SE of three replications, Column having the different letters differ significantly at $5 \%$ level of significance.

Table 3. The effect of plant extracts on the vegetative growth of Trichoderma viride (Green strain).

\begin{tabular}{llc}
\hline Sl. No. & Plant name & Mycelial inhibition (\%) \\
\hline 1. & Eclipta alba L. & $62 \pm 0.60 \mathrm{a}$ \\
2. & Pteris sp. L. & $49 \pm 0.44 \mathrm{~b}$ \\
3. & Diospyros cordifolia (Roxb.) & $44 \pm 0.32 \mathrm{c}$ \\
4. & Curcuma longa (leaf) L. & $44 \pm 0.53 \mathrm{c}$ \\
5. & Lantana camara L. & $31 \pm 1.15 \mathrm{~d}$ \\
6. & Pimenta acris Wt. & $31 \pm 2.01 \mathrm{~d}$ \\
7. & Rungia pectinata L.(Nees) & $29 \pm 0.20 \mathrm{~d}$ \\
8. & Cassia tora L. & $26 \pm 1.20 \mathrm{~d}$ \\
9. & Aegle marmelos (L.) Correa. & $26 \pm 0.58 \mathrm{~d}$ \\
10. & Curcuma longa (Rhizome) L. & $17 \pm 2.5 \mathrm{e}$ \\
$11-23$. & Others 13 botanical extracts & Nil \\
\hline
\end{tabular}

Data recorded at 7 days of incubation, Data represents mean \pm SE of three replications, Column having the same letters do not differ significantly at $5 \%$ level of significance.

Table 4. Effect of plant extracts on the vegetative growth of Trichoderma viride(Yellow strain).

\begin{tabular}{llc}
\hline Sl. No. & Plant name & Mycelial inhibition (\%) \\
\hline 1. & Cassia tora L. & $39 \pm 2.30 \mathrm{a}$ \\
2. & Rungia pectinata (L.) Nees & $37 \pm 1.58 \mathrm{a}$ \\
3. & Aegle marmelos (L.) Correa. & $31 \pm 0.60 \mathrm{~b}$ \\
4. & Pimenta acris Wt. & $30 \pm .80 \mathrm{~b}$ \\
5. & Eclipta alba L. & $29 \pm 0.57 \mathrm{~b}$ \\
$6-23$. & Others 18 botanical extracts & Nil \\
\hline
\end{tabular}

Data recorded at 7 days of incubation, Values represents mean \pm SE of three replications; Columns having the same letters do not differ significantly at $5 \%$ level of significance.

Table 5. Effect of plant extracts on the vegetative growth of Trichoderma koningii (Yellow strain).

\begin{tabular}{llc}
\hline Sl. No. & Plant name & Mycelial inhibition (\%) \\
\hline 1. & Diospyros cordifolia (Roxv.) & $48 \pm 2.05 \mathrm{a}$ \\
2. & Cassia tora L. & $41.4 \pm 1.56 \mathrm{~b}$ \\
3. & Blumea lacera (Burm f) & $40 \pm 0.60 \mathrm{~b}$ \\
4. & Mucuna pruriens L. & $37 \pm 1.20 \mathrm{~b}$ \\
5. & Rungia pectinata (L.) Nees & $33 \pm 0.58 \mathrm{C}$ \\
6. & Pimenta acris Wt. & $33 \pm 0.72 \mathrm{C}$ \\
7. & Aeglemarmelos (L.) Correa. & $33 \pm 2.63 \mathrm{C}$ \\
8. & Curcuma longa (leaf) & $27 \pm 0.60 \mathrm{C}$ \\
$9-23$. & Others 15 botanical extracts & Nil \\
\hline
\end{tabular}

Data recorded at 7 days of incubation, Values represents mean $\pm \mathrm{SE}$ of three replications, Columns having the same letters do not differ significantly at $5 \%$ level of significance.

The highest mycelial inhibition (90\%) of effect on mycelial growth of Neurospora sp as Neurospora sp. was recorded due to botanical well. The record of controlling measure of extracts of Curcuma longa (rhizome), followed by Neurospora sp. through botanicals was not Pteris sp. (83\%), Bougainvillea glabra (80\%) (Table 6) and others six phytoextracts namelyDiospyros cordifolia, Rungia pectinata, Pimenta acris, Cassia tora, Eclipta alba, and Blumea lacera showed significantly positive inhibitory available as to the knowledge of the author. In the present investigation, none of the 23 botanicals showed any significant effect against the mycelia growth inhibition of A. flavus, B. theobromae, Mucor hiemalis and P. byssina. 
Table 6. The effect of plant extracts on the vegetative growth of Neurospora sp.

\begin{tabular}{llc}
\hline Sl. No. & Plant name & Mycelial inhibition (\%) \\
\hline 1. & Curcuma longa (rhizome) & $90 \pm 1.20 \mathrm{a}$ \\
2. & Pteris sp & $83 \pm 1.60 \mathrm{~b}$ \\
3. & Bougainvillea glabra Choisy & $80 \pm 1.62 \mathrm{c}$ \\
4. & Blumea lacera (Thunb) & $66 \pm 1.80 \mathrm{~d}$ \\
5. & Eclipta alba L. & $66 \pm 1.95 \mathrm{~d}$ \\
6. & Cassia tora L. & $48 \pm 0.90 \mathrm{e}$ \\
7. & Diospyros cordifolia (Roxv.) & $48 \pm 1.30 \mathrm{e}$ \\
8. & Rungia pectinata (L.) Nees & $37 \pm 2.32 \mathrm{f}$ \\
9. & Pimenta acris Wt. & $33 \pm 1.50 \mathrm{~g}$ \\
$10-23$. & Others 14 botanical extracts & Nil \\
\hline
\end{tabular}

Data recorded at 7 days of incubation, Values represents mean \pm SE of three replications, Columns having the same letters do not differ significantly at $5 \%$ level of significance.

In-vitro effect of fungicide on vegetative Papulaspora byssina were inhibited by 30,50 growth of test fungus

A fungicide- Bavistin 50 WP (Carbendazim) was applied against the selected competitors to observe the antifungal efficacy (Table 7). Trichoderma harzianum was controlled at all of the concentration of Bavistin $50 \mathrm{WP}$ used. Trichoderma viride (Green strain), Trichoderma and $70 \mathrm{ppm}$ of Bavistin 50WP. However, best results obtained due to $70 \mathrm{ppm}$ concentration. Our results are supported by previous findings. The maximum mean inhibition (90.8\%) of Trichoderma harzianum and the least mycelial inhibition (24.9\%) of Pleurotus sajor-caju was recorded in Carbendazim (Shah et al., 2013). viride (Yellow strain), Trichoderma koningii, Aspergillus flavus, Neurospora sp. and

Table 7. Effect of Bavistin 50 WP on the mycelial growth of fungal competitors of mushroom.

\begin{tabular}{|c|c|c|c|}
\hline Sl. No. & $\begin{array}{l}\text { Name of fungal competitors of } \\
\text { mushroom }\end{array}$ & Concentration (ppm) & Mycelial inhibition (\%) \\
\hline \multirow{3}{*}{1.} & \multirow{3}{*}{ Trichoderma harzianum } & 30 & $99.50 \pm 0.28 \mathrm{a}$ \\
\hline & & 50 & $99.50 \pm 0.28 a$ \\
\hline & & 70 & $99.50 \pm 0.28 a$ \\
\hline \multirow{3}{*}{2.} & \multirow{3}{*}{ Trichoderma viride, (green strain) } & 30 & $84.44 \pm 0.00 c$ \\
\hline & & 50 & $91.11 \pm 0.00 b$ \\
\hline & & 70 & $97.77 \pm 0.00 a$ \\
\hline \multirow{3}{*}{3.} & \multirow{3}{*}{ Trichoderma viride, (yellowstrain) } & 30 & $82.00 \pm 0.06 c$ \\
\hline & & 50 & $91.11 \pm 0.57 \mathrm{~b}$ \\
\hline & & 70 & $97.77 \pm 0.00 a$ \\
\hline \multirow{3}{*}{4.} & \multirow{3}{*}{ Trichoderma koningii } & 30 & $88.80 \pm 0.05 \mathrm{c}$ \\
\hline & & 50 & $93.30 \pm 0.05 b$ \\
\hline & & 70 & $97.70 \pm 0.05 a$ \\
\hline \multirow{3}{*}{5.} & \multirow{3}{*}{ Aspergillus flavus } & 30 & $77.00 \pm 0.57 \mathrm{c}$ \\
\hline & & 50 & $91.00 \pm 0.57 \mathrm{~b}$ \\
\hline & & 70 & $97.00 \pm 0.00 \mathrm{a}$ \\
\hline \multirow{3}{*}{6.} & \multirow{3}{*}{ Neurospora sp } & 30 & $80.00 \pm 0.00 c$ \\
\hline & & 50 & $92.50 \pm 0.00 \mathrm{~b}$ \\
\hline & & 70 & $100.00 \pm 0.00 \mathrm{a}$ \\
\hline \multirow{3}{*}{7.} & \multirow{3}{*}{ Papulaspora byssina } & 30 & $37.77 \pm 0.00 \mathrm{c}$ \\
\hline & & 50 & $66.66 \pm 0.00 \mathrm{~b}$ \\
\hline & & 70 & $82.22 \pm 0.00 \mathrm{a}$ \\
\hline 8. & Botryodiplodia theobromae & $30,50,70$ & - \\
\hline 9. & Mucor hiemalis & $30,50,70$ & - \\
\hline
\end{tabular}

Here "-" No mycelial inhbition, Values represents mean \pm SE, Data recorded at 5 days of incubation, Columns having the same letters (of the respective fungal competitors ) do not differ significantly at $5 \%$ level of significance.

Carbendazim was also found to be efficiently inhibiting the mycelial growth green mould isolates (T. harzianum) at very low concentrations ( $0.63 \mu \mathrm{g} \mathrm{mL} \mathrm{m}^{-1}$ to $5 \mu \mathrm{g} \mathrm{mL} \mathrm{m}^{-1}$ ) and did not influence the growth of Oyster mushroom (Pleurotus ostreatus and button mushroom (Hatvani et al., 2012; Woo et al., 2004). Parvez et al. (2009) found that the combination of formalin and Carbendazim (500 $\mathrm{mL}+75 \mathrm{ppm}$ ) was the best in inhibiting the mycelial radial growth of all the identified microflora of oyster mushroom substrate. Maurya et al. (2013) reported that Carbendazim (0.05\%) exhibited strong antifungal properties which inhibited more than $80 \%$ mycelial growth of the T. harzianum and $\mathrm{P}$. byssina but mycelial growth of mushroom 
(Pleurotus florida) was unaffected against all the test fungicides concentration (0.05, 0.075 and 0.1\%). Botryodiplodia theobromae and Mucor hiemalis were not affected by Bavistin 50 WP at above mentioned concentration used which is in contradictory to Muhammad et al. (2009) who reported that Carbendazim showed complete inhibition of Botryodiplodia theobromae over at both 50 and 100 ppm doses.

In conclusion, fungicide-Bavistin was found to be effective to control a range of microflora associated with oyster mushroom substrate.

\section{References}

Alexopolus, C.J., Mims, C.W. and Blackwell, M. 1996. Introductory Mycology. 4th Ed. John Willey and Sons. Inc. pp. 359-361.

Ashrafuzzaman, M.H., Khan, A.R. and Hawladar, A.R. 1990. In vitro effect of lemon grass oil and crude extracts of higher plants on Rhizoctonia solani. Bangladesh J. Plant. Pathol. 6 (1\& 2): 17-18.

Barnett, H.L. 1960. Illustrated Genera of Imperfect Fungi. Second Edition. Burgees Pub. Co. Minneapoils, U.S.A. pp. 1-218.

Cappuccino, J.G. and Sherman, N. 1998. Microbiology A laboratory manual, $6^{\text {th }} \mathrm{Ed}$. Benjamin-Cummings Publishing Company, USA. 569 p.

Chen, A.W. and Moy, M. 2004. Mushroom cultivation: building mold contamination. Proceedings of $16^{\text {th }}$ ISMS International Congress, Miami, USA.

Chinara, N. and Mohapatra, K.B. 2014. Prevalence of competitor moulds and diseases in straw mushroom (Volvariella volvacea) beds and their management. Proceedings of the $8^{\text {th }}$ international conference on mushroom biology and mushroom products (ICMBMP-8)-2014, India. pp. 563-566.

Choi, I.Y., Choi, J.N., Praveen, K.S. and Lee, W.H. 2003. Molecular and Morphological Characterization of Green Mold, Trichoderma spp. isolated from Oyster Mushrooms. Korean Soc. Mycol. 31(2): 7480.

Colavolpe, M.B., Mejia, S.J . and Alberto, E. 2015. Efficiency of treatments for controlling Trichoderma spp. during spawning in cultivation of lignicolous mushrooms. Braz. J. Microbiol. 45(4): 1263- 1270.

Dano, J. 2000. Symptom expression of Trichoderma viride, T. koningii and $\mathrm{T}$. harzianum biotype Th1 on sporophore development of Agaricus bisporus. BSc Honour's Thesis, Brock University, St Catharines, Ontario, Canada. 95 p.
Dhingra, O.D, and Sinclair, J.B. 1985. Basic plant pathology methods, 2nd Ed, CRC Press, Inc. Boca Raton Florida, pp. 13-355.

Fletcher, J.T., White, P.F. and Gaze, R.H. 1989. Mushroom: pests and disease control. Intercept, Newcastle upon Tyne, England. $174 \mathrm{p}$.

Hatvani, L., Sabolić, P., Kocsubé, S., Kredics, L., Czifra, D., Vágvölgyi, C., Kaliterna, J., Ivić, D., Đermić, E. and Kosalec, I., 2012. The First Report on Mushroom Green Mould Disease in Croatia. Arch.Ind. Hygiene Toxicol. 63(4): 481-487.

Inam-ul-Haq, M., Khan, N.A., Khan, A., Khan, M.A., J aved, N., Binyamin, R. and Irshad, G. 2010. Use of medicinal plants in different composts for yield improvement of various strains of oyster mushroom. Pakistan J . Bot. 42: 3275-3283.

Maurya, S., Sharma, J.P. and Kumar, S. 2013. Effect of some common fungicides for the management substrate diseases of mushroom and mycelial proliferation of Pleurotus florida. Indian Mushroom Conference-2013, April 16-17, Punjab Agricultural University, Ludhiana, India, Abstract No. 85, 63 p.

Mishra, R.S. 2009. Management of Trichoderma viride on Button mushroom. Annal. Plant Protect. Sci. 17: 515-516.

Muhammad, S., Jafar. I., Saleem, A. and Anjum, M.A. 2009. Association of Lasiodiplodia theobromae with different decline disorders in mango. Pakistan J . Bot. 41(1): 359-368.

Narzari, M.K., Gogoi, R. and Puzari, K.C. 2007. Management of green mold of oyster mushroom by garlic extract. Indian Phytopath. 60: 322-326.

Parvez, Z, Bhuiyan, M.K.A. and Islam, M.S. 2009. In vitro control of associated mycoflora of oyster mushroom substrates by the application of fungicides. Bangladesh Res. Pub. J . 2: 737-741.

Parvez, Z., Islam, M.S. and Islam, S.M.A. 2012. Evaluation of some plant extracts in controlling green mold (T. harzianum) associated with substrate of oyster mushroom. Bangladesh Res. Pub. J. 7(3): 194-200.

Rinker, D.L. and Wuest, P.J. 1994. Pests of commercial mushroom production: Indicator Moulds. Mushroom World. 108: 11- 16.

Shah, S., Nasreen, S. and Munshi, N.A. 2011. Evaluation of Some Botanicals in Controlling Green Mold (Trichoderma harzianum) Disease in Oyster Mushroom Cultivation. Int. J . Bot. 7: 209-215.

Shah, S., Nasreen, S. and Kousar, S. 2013. Efficacy of Fungicides against Trichoderma spp. Causing Green Mold Disease of Oyster 
Mushroom (Pleurotus sajor-caju). Res. J. Siddique, A.B., Robin, G. and Puzari, K.C. 2004. Microbiol. 8(1): 13-24.

Sharma, S.R., Kumar, S. and Sharma, V.P. 2007. Diseases and Competitor Moulds of Mushrooms and their Management. Technical Bulletin. National Research Centre for Mushroom. Chambaghat, Solan, India. pp. 1-43.

Sharma, V.P. and Kumar, S. 2011. Competitor moulds and diseases in mushroom production and their management. Mushrooms cultivation, marketing and consumption. Directorate of Mushroom Research (ICAR), Chambaghat, India. pp. Evaluation of phyto-extracts against contaminants of Oyster mushroom. J. Mycol. Pl. Pathol. 34(2): 291-292.

Vincent, J.M. 1947. Distortion of fungal hyphae in the presence of certain inhibitors. Nature. 159: 850.

Woo, S.L., Di Benedetto, P., Senatore, M., Abadi, K., Gigante, S., Soriente, I., Ferraioli, S., Scala, F. and Lorito, M. 2004. Identification and characterization of Trichoderma species aggressive to Pleurotus in Italy. J. Zhejiang Univ. Agric. Life Sci. 30: 469-70. 